\title{
Fishers (Paraty, RJ) and fish manipulation time: a variable associated to the choice for consumption and sale
}

\author{
Begossi, A. ${ }^{a, b, c *}$, Salivonchyk, SV. ${ }^{d}$,Hanazaki, N. ${ }^{c, e}$, Martins, IM..$^{e}$ and Bueloni, F. ${ }^{e}$ \\ aPrograma de Capacitação de Pescadores Artesanais para o Manejo Pesqueiro - CAPESCA, \\ Laboratório de Estudos e Pesquisa em Artes e Ciências - LEPAC UNICAMP-Paraty, \\ Centro de Memória Unicamp - CMU, Universidade Estadual de Campinas - UNICAMP, CP 6023, Campinas, SP, Brazil \\ 'Programa de Pós-graduação em Sustentabilidade de Ecossistemas Costeiros e Marinhos - ECOMAR, \\ Universidade Santa Cecília - UNISANTA, Rua Oswaldo Cruz, 277, Santos, SP, Brazil \\ ${ }^{c}$ Fisheries and Food Institute - FIFO, www.fisheriesandfood.org \\ Institute for Nature Management, National Academy of Sciences of Belarus, 10 Fr. Skaryna Street, \\ Minsk, 220114, Minsk, Belarus

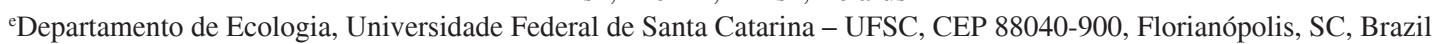 \\ *e-mail: alpinab@uol.com.br
}

Received March 12, 2012 - Accepted March 19, 2012 - Distributed November 30, 2012

(With 1 figure)

\section{Introduction}

The diet of human populations reveals a great part of the interactions with natural resources. Food categorisation and choices have been studied by many authors from the field of anthropology and human ecology (Messer, 1984; Hames and Vickers, 1982). Some authors have used optimal foraging theory to understand food choices (Begossi and Richerson, 1992; Hawkes and Vickers, 1982); in Brazil, the diet choice within small-scale fisheries have been studied by Begossi et al. (2004), Murrieta et al. (1999) and Hanazaki and Begossi (2004, 2006, among others). Recently, diet has been a part of studies on small-scale fisheries especially concerning resilience and food security that might be associated to conservation (Pomeroy and Andrew, 2011). In this study, we investigate some of the variables associated with the fish choice of two fishing communities of Paraty, RJ (Praia Grande and Tarituba). Both communities are important landing points of smallscale fishermen, where fish are sold directly at local fish markets. The choice of fish by fishermen's families is important because: a) there is a dilemma between consuming or selling the catch (Begossi and Richerson, 1992); b) target species are often concentrated on commercial fish, that are primarily sold and secondarily eaten (Nehrer and Begossi, 2000); c) management processes often include periods where fishing is not allowed for some species, having potential impacts in the food security of families.

\section{Methods}

Data was collected through interviews performed with residents of Praia Grande and Tarituba(Paraty) in JuneJuly 2011 (for details about the area see http://umanitoba. ca/institutes/natural_resources/Brazil/index.html). In an earlier study, the number of small-scale fishermen was estimated for Praia Grande as 20, and for Tarituba as 40 (Begossi et al., 2010). Fish identification can be found in Begossi et al. (2012). Shrimp is the most important landing in 2009-2011 at these sites (35\% of all biomass), followed by sand drum, bluerunner, weakfish, snook, and mullet (Begossi et al., 2012).

\section{Results}

We interviewed 73 inhabitants: 44 at Praia Grande (15 men, average age 49 years old; 29 women, average age 44 years old) and 29 at Tarituba (14 men, average age 53 years old; 15 women, average age 46 years old). The fish most cited as consumed in both communities and by both men and women were corvina (sand drum, Micropogonias furnieri) and tainha (mullet, Mugil spp.). Cavala (king mackerel, Scomberomorus cavalla) was cited especially by women from both communities, and pescadinha (weakfish, Cynoscion spp., among others) by women and men fromTarituba (Figure 1a). This fish, shown as pescada in Figure 1b, is not much cited as commercialised ("sold"), thus interviewees probably prefer to eat rather than to sell it. Robalo (snook, Centropomus spp.) was the fish most cited as eaten by all interviewees, and it has the highest price in the markets of both communities. Fish with fewer bones are preferred for commercialisation, as shown in Figure 1c, since the most cited as sold are also cited as less bony. Bony fish (Figure 1d) seem to be at the bottom in terms of usefulness by all interviewees. Fish cited as more available are also used for consumption and commercialisation (Figure 1e). Interestingly, the less available fish was sold, and cited especially by women from Praia Grande (Figure 1f). The most appreciated fish (preferred to be eaten) are also the less bony fish (Figure 1g).

These results reinforce data from previous studies that show that food with less time for manipulation (boniness, in this study) are preferred as food; such time of manipulation is an important variable also for fish to be commercialised 

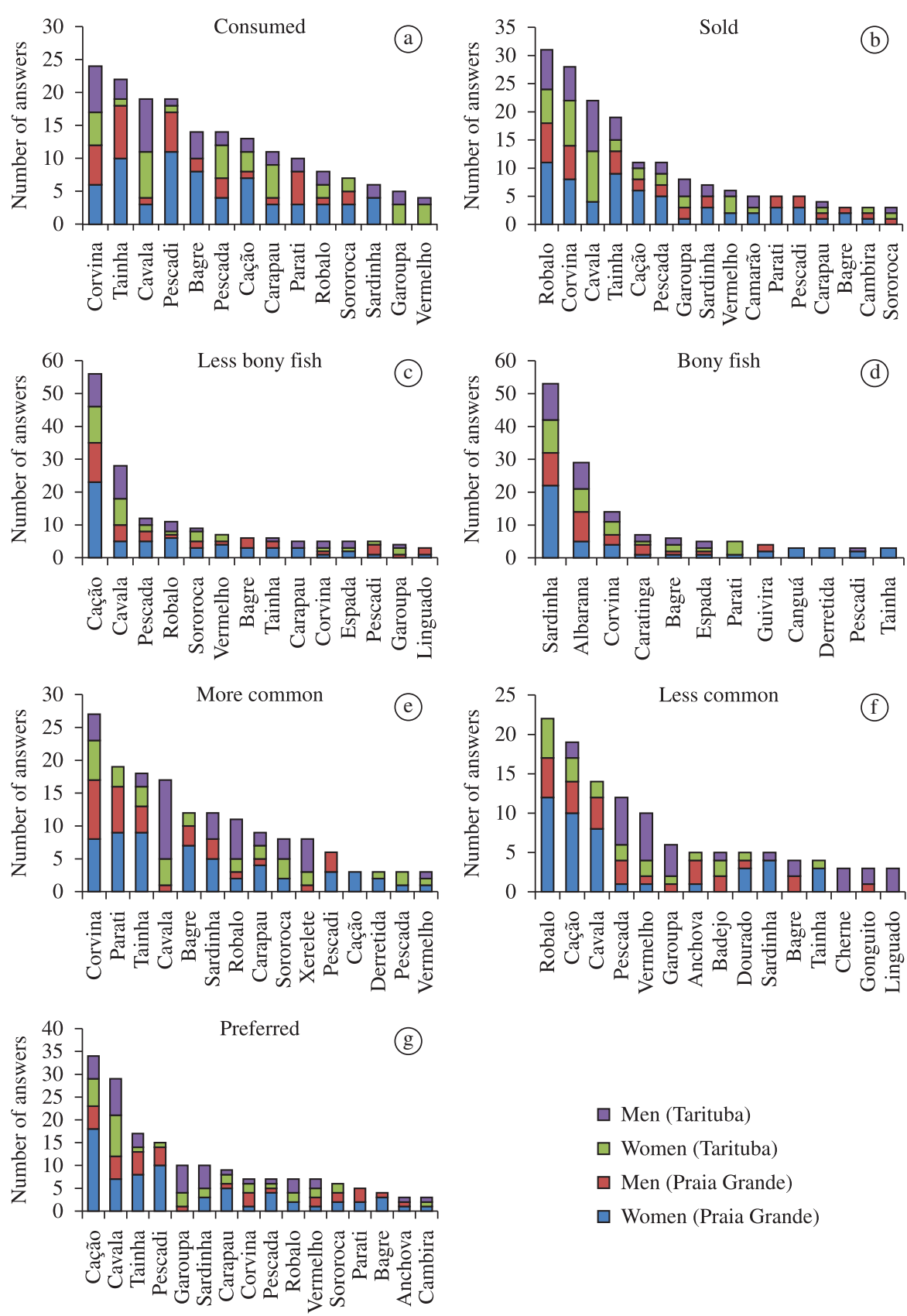

Figure 1. Results of citations from interviews (interviews or more) with men and women from the small-scale fisheries of Praia Grande and Tarituba in Paraty, RJ, Brazil. The number of fish cited in all interviews (common names) are: consumed (30), sold (23), less bony fish (28), bony fish (30), common (30), less common (36), and preferred (34).

(Begossi and Richerson, 1992; Nehrer and Begossi, 2000). These results reinforce the assumptions that come from optimal foraging theory, in which time of manipulation should decrease preference for food, since it increases time and effort of consumption. Processing time is part of the reason obtained to infer the ranking of food items in optimal foraging models. The more manipulation or processing time of a food, the less highly ranked it tends to be (the equation considers energy/searching plus handling).
Archaeologists also used optimal foraging models to estimate food preferences. Burger et al. (2005) observed that the time invested in extracting energy from a prey (a carcass) using processing efforts as a proxy for patch residence also reflects in the mean foraging return rate. In our study, the foraging time is increased by the necessity of food manipulation when bones need to be taken out of the fish. Especially when caring for children eating the fish, manipulation is much needed. No differences were 
found in gender concerning fish choices. Results here reinforce the importance of manipulation time in food choices, as predicted by optimal foraging models. It also showed that food choices are not restricted to culture, but are also influenced by biological attributes (fish boniness and time of manipulation for humans).Similar results in terms of boniness (Begossi and Richerson, 1992) and of other attributes of food choices and taboos (such as carnivory, toxicity) (Begossi et al., 2004; Hanazaki and Begossi, 2006) were found among small-scale fishers. Therefore, it is important to have an ample source of variables in order to understand the process of food choices in human populations.

Acknowledgements - We thank FAPESP (09/11154-3) and IDRC-Canada for grants, and CNPq for scholarships.

\section{References}

BEGOSSI, A. and RICHERSON, PJ., 1992. The animal diet of families from Búzios Island (Brazil): an optimal foraging approach. Journal of Human Ecology, vol. 3, p. 433-458.

BEGOSSI, A., HANAZAKI, N. and RAMOS, R., 2004. Food chain and the reasons for food taboos among Amazonian and Atlantic Forest fishers (Brazil). Ecological Applications, vol. 14, no. 5, p. 1334-1343. http://dx.doi.org/10.1890/03-5072

BEGOSSI, A., LOPES, PF., OLIVEIRA, LEC. and NAKANO, H., 2010. Ecologia de pescadores artesanais da baía da Ilha Grande. São Carlos: Rima.

BEGOSSI, A., SALYVONCHYK, SV., NORA, V., LOPES, PF. and SILVANO, RAM., 2012. The Paraty artisanal fishery (southeastern Brazilian coast): ethnoecology and management of a social-ecological system (SES). Journal of Ethnobiology and Ethnomedicine, vol. 28, no. 1, p. 22. PMid:22738073. http:// dx.doi.org/10.1186/1746-4269-8-22

BURGER, O., HAMILTON, MJ. and WALKER, R., 2005. The prey as patch model: optimal handling of resources with diminishing returns. Journal of Archaeological Science, vol. 32, p. 1147-1158. http://dx.doi.org/10.1016/j.jas.2005.02.012

HAMES, RB. and VICKERS, WT., 1982. Optimal diet breadth theory as a model to explain variability in Amazonian hunting. American Ethnologist, vol. 9, p. 358-379. http://dx.doi.org/10.1525/ ae.1982.9.2.02a00090

HANAZAKI, N. and BEGOSSI, A., 2004. Does fish still matter? Changes in the diet of two Brazilian fishing communities. Ecology of Food and Nutrition, vol. 42, p. 279-301. PMid:22260174. http:// dx.doi.org/10.1080/03670240390229643

HANAZAKI, N. and BEGOSSI, A., 2006. Catfish and mullets: the food preferences and taboos of Caiçaras (Southern Atlantic Forest Coast, Brazil). Interciência, vol. 31, no. 2, p. 123-129.

MESSER, E., 1984. Anthropological perspectives on diet. Annual Review of Anthropology, vol. 13, p. 205-249. http://dx.doi. org/10.1146/annurev.an.13.100184.001225

MURRIETA, RSS., DUFOUR, DL. and SIQUEIRA, A., 1999. Food consumption and subsistence in three Caboclo populations on Marajó island, Amazonia, Brazil. Human Ecology, vol. 27, p. 455-475. http://dx.doi.org/10.1023/A:1018779624490

NEHRER, R. and BEGOSSI, A., 2000. Fishing at Copacabana, Rio de Janeiro: local strategies in a global city. Ciência e Cultura, vol. 52, p. 26-30.

POMEROY, RS. and ANDREW, N., 2011. Small scale fishery management. Available from: <www.cabi.org $>$. 
